\title{
Creativity and Life Satisfaction in Spanish University Students. Effects of an Emotionally Positive and Creative Program
}

\author{
Presentación A. Caballero-García*t and Sara Sánchez Ruiz ${ }^{\dagger}$ \\ Faculty of Education, Camilo José Cela University, Madrid, Spain
}

\section{OPEN ACCESS}

Edited by:

Alexander Muela,

University of the Basque Country,

Spain

Reviewed by:

Eva Viola Hoff

Lund University, Sweden

Romualdas Malinauskas,

Lithuanian Sports University, Lithuania

Teresa Pozo-Rico,

University of Alicante, Spain

*Correspondence:

Presentación A. Caballero-García

pcaballero@ucjc.edu

tThese authors have contributed equally to this work and share first

authorship

Specialty section:

This article was submitted to

Educational Psychology,

a section of the journal

Frontiers in Psychology

Received: 23 July 2021 Accepted: 09 November 2021 Published: 06 December 2021

Citation:

Caballero-García PA and Sánchez Ruiz S (2021) Creativity and Life Satisfaction in Spanish University Students. Effects of an Emotionally

Positive and Creative Program.

Front. Psychol. 12:746154.

doi: 10.3389/fpsyg.2021.746154
There is an increasing demand by society that university students demonstrate competitive skills to enable them to achieve greater success when entering the workplace. Creativity and life satisfaction correlate positively with academic performance, productivity, and excellence in the working environment. The presence of creativity and emotional intelligence in the curriculum and teaching methods in Spanish universities, however, is surprisingly lacking. Studies that examine gender differences in these variables provide conflicting results. The purpose of our research is to analyse the changes produced in both creativity and life satisfaction in university students by a positive emotional and creative intervention and explore individual differences by gender. The methodology used was a quasi-experimental pre- test/post- test design with experimental/control groups. Three hundred university students (23\% men and $77 \%$ women) from the Community of Madrid (Spain) completed three exercises that evaluated creativity and life satisfaction. The results show significantly higher results in creativity and life satisfaction in women, who continued to achieve high results after the intervention. Finally, we discuss the need for emotional and creative education in universities and focus on the employability and the guarantee of equal opportunities through the development of these competencies.

Keywords: creativity, life satisfaction, higher education, key competences, employability

\section{INTRODUCTION}

Today it is increasingly important that students leave university with the necessary skills and ability to demonstrate that they are competitive as this will enable them to achieve greater success when entering the workplace. Creativity and life satisfaction contribute to this skill, as they help nurture both personal and social development, and are positively related to academic performance (Figueiredo-Ferraz et al., 2009; Anwar et al., 2012; Belmonte, 2013; Saremi and Bahdori, 2015; Bernabé et al., 2017; Peña García et al., 2017), productivity, excellence at work (De Ávila et al., 2019) and the ability to be innovative. 
The European reference framework focuses on the need for creativity to be a key aspect on which the rest of the competencies be based and emphasizes its importance in university students' overall learning processes (Álvarez-Santullano and De Prada Creo, 2018). It has even stated that creativity is one of the educational focal points of the XXI century (Carnero Sánchez et al., 2020). Since 1996, The Cotec Foundation (Cotec Fundation, 2020) has highlighted Spain's potential in research, development and innovation, and the prospect of this becoming Spain's best weapon in fighting against future global shocks and achieving a balance between social well-being, prosperity and environmental sustainability.

However, it is surprising to still see the lack of inclusion of these generic or transversal competencies within the educational system (Hernández Arteaga et al., 2015), their inadequate presence in the curriculum of Spanish universities (Porto, 2008) and in teaching approaches used nowadays (CaballeroGarcía and Sánchez, 2018; Caballero-García et al., 2019). As we move into higher education and professional life, creativity is lost, to find an orientation toward productivity (LimiñanaGras and Javier, 2010). Cotec's 2010 report highlighted lower levels in creativity and innovation in young Spanish university students when compared to European students (Pérez-Díaz and Rodríguez, 2010; cited by Secanella, 2016). In the same vein, studies such as those of Álvarez-Santullano and De Prada Creo (2018) evaluated the professional competencies of university students and concluded that the average across all the competencies such as technical ability, organizational skills, oral and written communication skills, initiative, motivation, and teamwork were high. The exception was creativity, hence our interest in the analysis of the lack of creativity in our university students.

Creativity is multidimensional, polysemic, and a concept that is difficult to understand (Amabile, 1983; De La Torre, 1991; Garaigordobil, 2003; Serrano, 2004). There doesn't seem to be any single definition or single method of measurement (Elisondo and Donolo, 2011). This has resulted in the construction of different tools to assess creative capabilities, design, and creative achievements in a real context and in everyday life situations. The Creative Intelligence Test (CREA) by Corbalán et al. (2003) “is one of these valuable initiatives" (p. 78), it measures capability to be creative, divergent production, originality, and fluency and stands out for its technical and practical properties (Elisondo, 2015). As for the explanatory models of creativity, the taxonomy by antonomasia is one that focuses on creativity as a cognitive process (Tristán López and Mendoza González, 2016). Hence, our research is based on the analysis of this perspective, and the CREA test used as our measurement tool.

CREA test is theoretically based on the classic factors of creativity (divergent production, flexibility, fluency, and originality) and on the approaches of problem formulation, lateral thinking, and the study of cognitive styles (Corbalán and Limiñana Gras, 2010). It is cataloged as a cognitive measure of individual creativity according to the indicator of question generation, in the theoretical context of problem finding and problem solving, and the concept of creativity of Amabile (1983) and other authors such as Sternberg (1988) and Weisberg (1988) who define the creativity as a production of novel, useful ideas or problem solutions.

Studies by Corbalán et al. (2009) show that the CREA test is a creativity assessment instrument that shows predictive ability with statistical significance. Its statistical justification is supported, both by the size of its normative sample, close to 2,500 cases, the convergent and divergent validity indices, reliability, and other descriptive and inferential indicators; and by the adaptation of the variable's behavior to theoretical predictions and research precedents, with respect to what is expected in relation to different classical measures of creativity. Another motive to choose this tool is due to the numerous empirical studies in which it has been used, as well as in interventions in different fields, which show its good psychometric characteristics, and the reliability and validity of its data on the creativity of the subject (see Corbalán and Limiñana Gras, 2010).

All these reasons that make the CREA test a statistically reliable and conceptually valid measure of creativity are what led us to use it as a measure of creativity in our study, in addition to its simplicity and ease of administration to the subjects in the sample.

Life satisfaction, on the other hand, is a variable characterized by its subjectivity. In our research it has been considered as a cognitive process of subjective well-being (Diener, 2000). It can be defined as a global cognitive judgment of one's life. The evaluation carried out is not an evaluation based on objective parameters. It implies the person's own global interpretation of his or her own happiness and life satisfaction. And, to understand it, it is necessary to consider indirect variables of a contextual or personal nature that may influence this judgment (Diener, 1994). This makes it difficult to measure, which is why it is necessary to use a method that evaluates satisfaction orientated to specific contexts and populations (Okun et al., 1984) or more than a single evaluation measure which has adequate validity and reliability (retest and convergent test). For this, our study uses the Satisfaction with Life Scale of Diener et al. (1985) and the Overall Life Satisfaction of Campbell et al. (1976), two of the most used in this area.

The Manifesto for Adult Learning in the 21st century of the European Association for The Education of Adults (European Association for the Education of Adults [EAEA], 2019) presents nine challenges to transform adult education in Europe. These include health and well-being (in which life satisfaction is highlighted for its contribution to personal development and the construction of healthier societies), people's life skills; employment and work (where creativity is a competence that offers new employment opportunities and increases innovation and productivity at work); and social cohesion, equity, and equality; all of which are linked to the variables of our study.

Studies show that students with greater life satisfaction, are more likely to successfully complete their university studies (Figueiredo-Ferraz et al., 2009). This well-being is also linked to employability (Lantarón, 2012), as the personal skills acquired by the student are reflected favorably when presenting themselves as candidates in the labor market. Authors such as Graen (1976) and Diener and Biswas-Diener (2002) show that students with greater well-being end up performing jobs with greater responsibility 
and better pay. These results justify the need for an education in socio-emotional competence within a university education (Lantarón, 2014).

The implementation of initiatives to develop creativity and life satisfaction in an educational environment can be seen in action plans, programs, and initiatives, both at international and national level and show satisfactory results (Sánchez Ruiz, 2020). In relation to intervention programs carried out in university classrooms with the aim of stimulating creative thinking, there are some examples at international level such as: the "Edmodo" program, developed with students a Tabuk University, to teach mathematics (MATLAB) by developing creative, cognitive and affective skills (Goda, 2019); the program by Vally et al. (2019), which trained the creative production skills of resident students in the Arab Emirates; the "ADAPT" program developed in 1980 by Moshman, Johnston, Tomlinson-Keasey, Williams, and Eisert at Lincoln University of Nebraska; the "DOORS" program, developed in 1977 at Central Illinois University; the "COMPAS" program, carried out in seven universities by Schermerhorn, Williams and Dyckison (between 1979 and 1982); the "SOAR" program, developed at Xavier University in Louisiana (between 1977 and 1978); and the "DORIS" program (development of reasoning in science) carried out at California State University (1980). At national level, we can see examples such as The Botín Foundation (Botín Fundation, 2012) which enhance the development of creativity through art and emotions, and Allueva (2004) whose participants were students of psychopedagogy from the University of Zaragoza, where 142 interventions of creativity were carried out, obtaining medium to high differences in the pre-test/post-test results.

Programs aimed at working on life satisfaction with university students have also been shown to be effective in improving wellbeing and decreasing symptoms of depression, which can be deduced from the results of meta-analyses such as those of Sin and Lyubomirsky (2009). Even though the programs showed slightly improved well-being and depression, the results stabilized over a period of time (Bolier et al., 2013; Ovejero et al., 2015). Other examples of these are: the program by Remor et al. (2010); the positive psychology program by Ovejero et al. (2015); the program by Arroyo-Resino and Carrasco-Temiño (2017); and the program by Montenegro et al. (2017) amongst others.

The positive emotional and creative intervention program (EPOCREU) was implemented in this study based on a systematic review of the paper (Sánchez Ruiz, 2020). It is based on the EI ability model of Salovey and Mayer (1990); the theoretical approaches of Diener et al. (1999), Lyubomirsky and Lepper (1999), Limiñana Gras et al. (2010), and the recommendations for the development of creative thinking by authors such as Martín and Martín (2012) and Ramírez and Fuentes (2013). The intervention was designed in an ad hoc way, with its goal being to work on positive emotions and develop creative thinking in an integrated way in a normal classroom environment, improve the performance and competencies of emotional intelligence, improve creativity and happiness, and enhance life satisfaction of the university students who were part of the experimental group as well as to find empirical arguments to promote strategies of methodological change at the university.
Finally, studies that have analyzed gender differences in creativity offer contradictory data (Acevedo, 2012; Sánchez Ruiz, 2020). There are researchers such as Maccoby and Jacklin (1974), Wright and Stone (1998), De Zubiría et al. (2003), Chacón and Moncada (2006), Matud et al. (2007), Baer and Kaufman (2008), Limiñana-Gras and Javier (2010), Bermejo et al. (2013), and Ramírez et al. (2019) who conclude that creative potential is not influenced by the gender variable.

Other authors have found slight differences in the mean when measuring creativity by gender in favor of females, but these results have not proved to be significant (Naderi et al., 2009; Chiecher et al., 2018; Hidalgo Fuentes et al., 2018; Echegaray Antay, 2019; Barbachán Ruales et al., 2020). Finally, there are authors who have managed to confirm these differences in creativity in favor of women (Lee, 2005; Bindu and Thomas, 2006; Miranda, 2007; Limiñana-Gras and Javier, 2010; Krumm et al., 2015; Elisondo and Donolo, 2016; and Gamarra-Moscoso and Flores-Mamani, 2020, among others). Only a few research studies have found significant differences in creativity in favor of men (Zheng and Xiao, 1983; Tegano and Moran, 1989; Cox, 2003).

Some meta-analyses such as those of Baer and Kaufman (2008) or bibliographical reviews such as those of Villamizar Acevedo (2012) confirm the heterogeneity of the results obtained in gender differences in creativity research and highlight the importance of carrying out research with a sample of university students, given that studies with this type of student body in this area are scarce, hence our interest in exploring.

Regarding the gender differences in life satisfaction, as was the case with creativity, the research results are contradictory. Some authors have found significant differences in life satisfaction in favor of women in specific contexts or situations, such as in the educational field (Gilman et al., 2008; Casas et al., 2012; Cenkseven-Önder, 2012), in social relationships, the environment (Gilman et al., 2008; Chaplin, 2009; CenksevenÖnder, 2012); and overall life satisfaction (Gilman et al., 2008; Cenkseven-Önder, 2012; Chen and Lin, 2014). Whereas men score higher on satisfaction with sport (Chaplin, 2009); health and fitness (Woynarowska et al., 2004; Bisegger et al., 2005). Nevertheless, the conclusion drawn is that the measurement of emotional aspects of life satisfaction are more sensitive to gender differences. Women show greater satisfaction when evaluated from an emotional dimension, and the results tend to be more contradictory when measured from a cognitive dimension (Costa et al., 1987; Azpiazu, 2016), which is why some authors have justified the varying range of results because of the differing methods used for measurement (Bedin and Sarriera, 2015).

Studies of gender differences in life satisfaction in university students also offer heterogeneous results, hence our interest in contrasting this circumstance in our students. For the most part, the results show the mean values in favor of women, however they do not find significant differences in life satisfaction according to gender (Cardona and Agudelo, 2007; Gavín-Chocano and Molero-López, 2019; Jurado Guillen, 2019; Motta Taminchi, 2019; Poquioma, 2019). There are few studies that corroborate the significance of such differences in favor of women (Arocena et al., 2005; Lalive et al., 2014; Al-Attiyah and Nasser, 2016; 
Rojas-Valverde and Fallas-Campos, 2017; Cañero et al., 2019). Some research using even smaller groups found differences in life satisfaction in favor of men (Pavot et al., 1991; Smith et al., 1999; Bernal et al., 2011; Lukaschek et al., 2017; Tomyn and Weinberg, 2018). Recent research has shown greater interest in studying this variable because of COVID-19. The results indicate that men possess greater life satisfaction than women (Vizoso, 2019; Lozano-Díaz et al., 2020).

On the basis of the foregoing, our objectives were: (1) to describe creativity and life satisfaction of our university students, (2) to analyze the changes produced in both creativity and life satisfaction by a positive emotional and creative intervention integrated into regular classroom and (3) explore individual differences by gender in these variables, in order to promote their development in both general educational system and particular university system, under conditions of equality and competence. This makes our research part of the studies that promote a change in university education toward higher quality training based on competencies for life.

\section{MATERIALS AND METHODS}

\section{Participants}

Three hundred university students, aged between 18 and 47, from the Community of Madrid (Spain) (23\% men and $77 \%$ women) participated in our study. The sample was selected through non-probability and incidental sampling type 4 (Onwuegbuzie and Collins, 2007), often used in disciplines within education (Garrett, 1953) and useful in survey research (Pathak, 2008) like ours.

Of the total sample, one hundred and sixty-two students (54\% of the total amount), one hundred and twenty-two of them women $(40.7 \%)$ and forty men $(13.3 \%)$, were randomly assigned to the experimental group by the researchers. The control group was made up of the remaining one hundred and thirty-eight students (66\%), one hundred and ten of them being women (36.7\%) and twenty-eight being men (9.3\%). This random assignment of groups was performed prior to data collection and using an intact classroom procedure.
Following the recommendations of Campbell and Fiske (1959), Campbell and Stanley (1966), Pedhazur and Schmelkin (1991) and Stuart and Rubin (2008), to guarantee the internal validity of the study, we used random assignment of groups experimental/control (already mentioned) and repeated verification of the presence/absence of the treatment (predictive validity). The group equivalence was preserved by using homogeneity $\left(\chi^{2}\right)$ /homoscedasticity (Levene) tests and the effectiveness of the treatment in post-test measurements was guaranteed with statistics contrast effect ( $U$ de Mann Whitney test, analysis of the differences in the percentages of change pre/post-test, and effect size calculations). The results of $\chi^{2}$ led us to assume the homogeneity of the samples (group by gender $\left.\chi^{2}=0.824, p=0.364\right)$; the Kolmogorov Smirnov test, that there is no normality (neither in creativity nor in life satisfaction pre/post-test, by group and gender) (see Table 1), and Levene's test that there is not homoscedasticity in CREA $\mathrm{C}$ pre-test and CREA $\mathrm{A}$ and $\mathrm{B}$ post-test by group, nor in CREA C pre-test by gender (see Table 2), which forced us to use non-parametric methods. To ensure external validity, we try to preserve ecological validity by performing the experiment in a situation similar to that in which the results will be generalized.

\section{Design and Procedure}

The study employed was a quasi-experimental design with repeated pre-test/post-test measures and a non-equivalent control group (Cook and Campbell, 1979, 1986; León and GarcíaCelay, 2015).

The procedure followed was: (1) inform the participants of the research objectives and request their voluntary collaboration; (2) with those who agreed to collaborate and had communicated their informed consent, we carried out the pre-test evaluation, in a class session lasting approximately one hour; (3) the intervention program was carried out in the experimental groups while the control groups received the regular institutional program; (4) after the intervention, the post-test evaluation was carried out, in which the same instruments as at pre- test were administered to both groups (both groups were administered both instruments at pre-test and post-test); (5) finally, the data was tabulated and statistically treated.

TABLE 1 | Kolmogorov Smirnov test for creativity and life satisfaction (pre/post-test), by group and gender.

\begin{tabular}{|c|c|c|c|c|c|c|c|c|c|c|}
\hline \multirow{2}{*}{ Grupo } & \multicolumn{6}{|c|}{ Creativity } & \multicolumn{4}{|c|}{ Life satisfaction } \\
\hline & \multicolumn{2}{|c|}{ CREA A } & \multicolumn{2}{|c|}{ CREA B } & \multicolumn{2}{|c|}{ CREA C } & \multicolumn{2}{|l|}{ SWLS } & \multicolumn{2}{|l|}{ OLS } \\
\hline Control & 0.155 & $0.000^{*}$ & 0.129 & $0.000^{*}$ & 0.21 & $0.000^{*}$ & 0.218 & $0.000^{*}$ & 0.156 & $0.000^{*}$ \\
\hline Experimental & 0.174 & $0.000^{*}$ & 0.168 & $0.000^{*}$ & 0.175 & $0.000^{*}$ & 0.21 & $0.000^{*}$ & 0.124 & $0.000^{*}$ \\
\hline Hombre & 0.19 & $0.000^{\star}$ & 0.151 & $0.001^{*}$ & 0.163 & $0.000^{*}$ & 0.141 & $0.002^{*}$ & 0.187 & $0.000^{*}$ \\
\hline
\end{tabular}

CREA A, B, C = A, B, C CREA test pictures; SWLS (Satisfaction with Life Scale); OLS (Overall Life Satisfaction); c. Corrección de significación de Lilliefors; $p=$ Statistical significance, ${ }^{*} p<0.005$. 
TABLE 2 | Levene's test for creativity and life satisfaction (pre/post-test), by group and gender.

\begin{tabular}{|c|c|c|c|c|c|c|c|c|}
\hline & \multicolumn{4}{|c|}{ Group } & \multicolumn{4}{|c|}{ Gender } \\
\hline & $\begin{array}{l}\text { Levene's } \\
\text { test }\end{array}$ & $d f 1$ & $d f 2$ & $p$ & $\begin{array}{l}\text { Levene's } \\
\text { test }\end{array}$ & $d f 1$ & $d f 2$ & $p$ \\
\hline \multicolumn{9}{|c|}{ Creativity } \\
\hline \multicolumn{9}{|l|}{ Pre-test } \\
\hline CREA A & 2.132 & 1 & 298 & 0.145 & 0.071 & 1 & 298 & 0.789 \\
\hline CREA B & 0.055 & 1 & 298 & 0.814 & 0.061 & 1 & 298 & 0.805 \\
\hline CREA C & 5.392 & 1 & 298 & $0.021^{*}$ & 5.957 & 1 & 298 & $0.015^{\star}$ \\
\hline \multicolumn{9}{|c|}{ Post-test } \\
\hline CREA A & 3.934 & 1 & 298 & $0.048^{*}$ & 1.041 & 1 & 298 & 0.309 \\
\hline CREA B & 5.352 & 1 & 298 & $0.021^{*}$ & 0.409 & 1 & 298 & 0.523 \\
\hline CREA C & 0.807 & 1 & 298 & 0.370 & 0.017 & 1 & 298 & 0.895 \\
\hline \multicolumn{9}{|c|}{ Life satisfaction } \\
\hline \multicolumn{9}{|l|}{ Pre-test } \\
\hline OLS & 0.016 & 1 & 298 & 0.900 & 1.801 & 1 & 298 & 0.181 \\
\hline SWLS & 0.054 & 1 & 298 & 0.816 & 1.343 & 1 & 298 & 0.247 \\
\hline \multicolumn{9}{|c|}{ Post-test } \\
\hline OLS & 0.061 & 1 & 298 & 0.805 & 0.611 & 1 & 298 & 0.435 \\
\hline SWLS & 2.889 & 1 & 298 & 0.09 & 2.527 & 1 & 298 & 0.113 \\
\hline
\end{tabular}

CREA $A, B, C=A, B, C$ CREA test pictures; SWLS (Satisfaction with Life Scale); OLS (Overall Life Satisfaction), $p=$ Statistical significance, ${ }^{*} p<0.005$.

Combined with informed consent, both anonymity and the confidentiality of responses were always guaranteed (Punch, 1986; Meo, 2010; Miguélez, 2016), as well as the ethical values required in research. We respected the ethical principles and guidelines for research involving human subjects.

\section{The Intervention Program}

The intervention program was developed in the second semester (February-June) of the 2017/18 academic year, on a similar dose to all students, in normal classroom conditions, during school hours, and incorporated in the program of each participating subject's degree in the fields of Education and Health.

The objective of the program was to develop creative thinking and the subjective well-being of the students. The experimental conditions were performed in 8 groups with 18-23 students in each group. Each group was given on an average 7 (between 7 8 ) sessions (4 about life-satisfaction and 3 about creativity) of 60 min each in which 30 different activities were performed (17 of positive emotional education and 13 of creativity) (see Appendix for more information) during four months. We used different group dynamic techniques such as brainstorming, cooperative learning, role-playing, pair work, image association, information search, critical reflection, debate, case study, emotional fans, emotional self-awareness, communication, emotional regulation, empathy, etc.). The sessions were structured as follows: statement of objectives, development, and evaluation of the activity in terms of experience and learning.

The implementation of the program followed these steps: (a) previous training (first semester) of the six participating teachers in creative techniques and positive emotional management; (b) cooperative work sessions for the design of the tasks and techniques to be developed in the classroom; (c) sessions for consensus and selection of the activities to be adapted to the classroom and subject matter within the syllabus (second semester); (d) follow-up sessions and (e) evaluation sessions.

\section{Assessment Instruments}

Creativity was measured using CREA test by Corbalán et al. (2003). It is a cognitive measure of creativity, of an individual or collective. It is based on the generation of written questions during 4 min from 3 types of visual stimuli (pictures): picture A (advisable from 10 years old to adults), picture B (advisable from 12 years old to adxults), and picture $C$ (advisable from 616 years old to adults). It is used in children (from 6-11 years old), adolescents (from 12-16 years old), and adults (from age 16 years old), and has pre-existing tables of results for populations in Spain and Argentina. Unlike other tests that measure the same construct, this test identifies people's creative potential rather than achievements and evaluates the creative process according to theories such as those of Beghetto and Kaufman (2007, cited by Corbalán and Limiñana Gras, 2010). The amount of creative production generated by individuals is explained in terms of cognitive flexibility. In that versatility in the use of cognitive schemas (Arrieta Arias, 2019), observable through the Socratic method of question generation, the authors of the test see an indicator of creative talent and a measure of original and effective creativity. Far from attempting to directly assess creative behavior as traditionally done, the CREA test places the subject in the opposite situation to the one he or she usually encounters in everyday life: asking questions, rather than giving answers, as well as in different cultures, cities, and countries. This test offers single overall creativity data (direct score) that is compared with a centile score and interpreted as high (75-99), medium (26-74), or low (1-25) creativity and has demonstrated to be a predictor of the traditionally used dimensions of creativity (Corbalán and Limiñana Gras, 2010). It has a reliability of 0.875 , in the use of model A and model B as parallel models, and has concurrent validity of 0.792 , when comparing model A with the Guilford Creativity Battery. It meets, therefore, the basic standards of reliability and validity for the psychometric assessment of creativity (Corbalán et al., 2003; Martínez Zaragoza, 2003; Limiñana-Gras and Javier, 2010; Elisondo, 2015). In our study, the Kendall's coefficient of Concordance among rater's value achieved was close to strong (Schmidt, 1997) $(W=0.681)$ and the Cronbach's $\alpha$ value was: CREA A, 0.80; CREA B, 0.77 and CREA C, 0.81 ), and 0.90 for the test set. All these values are between 0.70 and 0.90 and indicate good internal consistency (Nunnally, 1978; Murphy and Davidshofer, 2005; Oviedo and Arias, 2005; Kaplan and Saccuzzo, 2009).

Life satisfaction was measured using the life satisfaction scale (SWLS) of Diener et al. (1985) in its Spanish version (Vázquez et al., 2013), and the single-item measure of life satisfaction, Overall Life Satisfaction Scale (OLS) of Campbell et al. (1976). SWLS is a self-evaluation scale that assesses cognitive aspects of well-being; specifically, the degree of satisfaction that the person perceives overall in his or her life. It can be used with both young people and adults (Pavot et al., 1991). The person examines the tangible aspects of his or her life, weighs the good against the bad, compares it with a standard or criterion chosen by him or 
her, and arrives at a judgment about one's satisfaction with his or her life. It consists of 5 items, which are easy to understand and easy and quick to respond to. The response possibilities range from 1 to 7 , where 1 is that they completely disagree and 7 is that they completely agree. The total score on the scale ranges from a minimum of 5 points to a maximum of 35 points. For this research the interpretation normative data proposed by Pavot and Diener (1993) were used: 31-35, very high score; very or highly satisfied people; 26-30, high score, satisfied people; 21 25, average score, people a little satisfied; 20, neutral; 15-19, slightly below average, a little unsatisfied; 10-14, dissatisfied, and 5-9, very or extremely dissatisfied. The Spanish version presents satisfactory psychometric properties in a sample of university students (Borrero et al., 2010). The internal consistency of the scale is adequate (Cronbach's $\alpha=0.84$ ) and like that obtained in other studies: Atienza et al. (2000), $\alpha=0.84$; Reig et al. (2001), $\alpha=0.83$ and Cabañero et al. (2004), $\alpha=0.82$. In our research we obtained a Cronbach's $\alpha$ value of.81, remarkably similar to reference studies, indicating good internal consistency (Nunnally, 1978; Murphy and Davidshofer, 2005; Oviedo and Arias, 2005; Kaplan and Saccuzzo, 2009).

The OLS is a single-item scale that assesses overall life satisfaction through the question: To what extent are you satisfied with your life in general? and has a Likert-type response scale of $0-10$ response alternatives where 0 means completely dissatisfied and 10 means completely satisfied. It presents adequate convergent validity with other measures of satisfaction in students, such as the SLSS, the BMSLSS, and the PWI-SC, with correlation coefficients ranging from $r=0.50$ to $r=0.62$ for Chilean, Brazilian, Spanish, and Romanian students (Casas et al., 2015).

\section{Analysis of Data}

We carried out a descriptive analysis of the sociodemographic variables, creativity, and life satisfaction (frequencies, percentages, means, and standard deviations), to discover the characteristics of the sample and the levels of these variables in the students of our sample before the intervention (pre-test), as well as we have calculated the medians of the variables studied to estimate Levene's values (see Table 3 ).
Next, we studied the homogeneity of samples (Pearson's chi-square) by group (experimental/control) and gender (men/women), and both the normal distribution (KolmogorovSmirnov) and homoscedasticity (Levene) of the sample, considering the condition of "greater than thirty individuals" (Haier et al., 2014). As neither normality nor homoscedasticity assumptions were met in all cases, we applied non-parametric statistics (Mann Whitney $U$ ) to assess the treatment effect in the different groups (experimental vs. control, and men vs. women). In the cases in which we found significant differences, we calculated the effect size or Cohen's $d$ (Cohen, 1988) to evaluate its strength or magnitude, using Cohen's criteria as a reference: small (0.20), medium (0.50), large (0.80).

In view of our need to reduce the experimental error derived from non-randomization in sample selections, in addition to the necessity to pinpoint the treatment effects of our quasiexperiment (Badii et al., 2017), we also calculated differences in the percentages of change pre/post-test. All these analyses (percentages of change and effect size) combined with Mann Whitney $U$ helped to quantify and adjust the treatment means and interpret the nature of the treatment effect on the dependent variables analyzed (post-test) for each of the groups (experimental vs. control; men vs. women).

Statistical analysis of the data was performed with IBM SPSS (version 25) statistical software for Windows; with a margin in the level of accuracy of $95 \%$ and an error level of 5\% (statistical significance level of $\alpha=0.05$ ).

\section{RESULTS}

\section{Creativity and Life Satisfaction of the Participants}

In response to the first objective, we present the creativity and life satisfaction level data of the participants. The students obtained a higher average pre-test centile score in creativity in picture $\mathrm{C}(M=68.80, S D=27.08)$, followed by picture $\mathrm{B}$ $(M=44.50, S D=27.24)$ and picture $\mathrm{A}(M=37.25, S D=25.70)$. This indicates, according to the test scale, that they present moderate levels of creative production (medium creativity). They

TABLE 3 | Descriptive analysis's creativity and life satisfaction (pre/post-test), by group and gender.

\begin{tabular}{|c|c|c|c|c|c|c|c|c|c|c|c|c|c|}
\hline & \multirow{2}{*}{$\begin{array}{l}\text { Creatividad/ } \\
\text { Life satisfaction }\end{array}$} & \multicolumn{3}{|c|}{ Control } & \multicolumn{3}{|c|}{ Experimental } & \multicolumn{3}{|c|}{ Female } & \multicolumn{3}{|l|}{ Male } \\
\hline & & $M$ & $S D$ & $M e$ & $M$ & $S D$ & $M e$ & $M$ & $S D$ & $M e$ & $M$ & $S D$ & $M e$ \\
\hline \multirow[t]{5}{*}{ Pre-test } & CREA A & 42.29 & 25.67 & 40 & 32.95 & 25.01 & 25 & 37.34 & 25.63 & 35 & 36.91 & 26.12 & 25 \\
\hline & CREA B & 48.55 & 26.9 & 50 & 41.05 & 27.14 & 35 & 46.13 & 26.98 & 45 & 38.94 & 27.61 & 30 \\
\hline & CREA C & 73.16 & 25.78 & 80 & 65.09 & 27.67 & 75 & 70.4 & 25.818 & 80 & 63.35 & 30.58 & 75 \\
\hline & OLS & 7.45 & 1.53 & 8 & 7.75 & 1.46 & 8 & 7.65 & 1.46 & 8 & 7.47 & 1.62 & 8 \\
\hline & SWLS & 5.30 & 1.07 & 5.4 & 5.42 & 1 & 5.6 & 5.45 & 0.99 & 5.6 & 5.07 & 1.13 & 5.1 \\
\hline \multirow[t]{5}{*}{ Post-test } & CREA A & 47.6 & 25.42 & 50 & 49.35 & 28.27 & 45 & 48.74 & 27.357 & 50 & 47.88 & 25.788 & 45 \\
\hline & CREA B & 50.4 & 26.13 & 50 & 52.69 & 29.62 & 46.5 & 53.45 & 27.942 & 50 & 45.44 & 27.723 & 45 \\
\hline & CREA C & 68.59 & 27.39 & 77.5 & 75.37 & 23.78 & 80 & 73.06 & 25.866 & 80 & 69.51 & 25.076 & 72 \\
\hline & OLS & 7.62 & 1.47 & 8 & 7.87 & 1.55 & 8 & 7.79 & 1.48 & 8 & 7.63 & 1.63 & 8 \\
\hline & SWLS & 5.41 & 0.98 & 5.6 & 5.64 & 1.1 & 6 & 5.6 & 1.01 & 5.8 & 5.32 & 1.27 & 5.8 \\
\hline
\end{tabular}

CREA A, B, C = A, B, C CREA test pictures; SWLS (Satisfaction with Life Scale); OLS (Overall Life Satisfaction); $M=$ mean; $S D=$ standard deviation; Me = median. 
are not outstanding in their capacity for innovation or problem solving, although on occasion they manage to do so, they make imaginative suggestions and question how to solve the problems presented to them.

Regarding life satisfaction, the mean score of our students in OLS test was 7.61 points $(S D=1.50)$, on a scale of 1 to 10 , that can be interpreted as a medium-high overall satisfaction with life. These high mean scores are maintained when asked specifically about their ideal, current living conditions and achievements, and whether they would change anything about their life experiences, obtaining in SWLS test average results of 27 points $(S D=1.03)$, that indicate -according to the scale- a high score and that students are satisfied with life. People who score in this range love their lives and feel that things are going very well for them. Despite this, they have identified areas of dissatisfaction and improvement (Diener et al., 1985).

\section{Effects of the Intervention Program on Creativity and Satisfaction With Life}

When we study the effects of the intervention program on creativity (see Table 4) we observe that there are significant median differences by group in all the CREA test pictures $(\mathrm{A}, \mathrm{B}$, C) administered before the intervention $\left(U_{\mathrm{A}}=8723, p=0.001\right.$; $\left.U_{\mathrm{B}}=9435, p=0.020 ; U_{\mathrm{C}}=9354, p=0.015\right)$ in favor of the control group $\left(M e_{\mathrm{A}}=40 ; M e_{\mathrm{B}}=50\right.$ and $\left.M e_{\mathrm{C}}=80\right)$ compared to the experimental group: $\left(M e_{\mathrm{A}}=25, M e_{\mathrm{B}}=35\right.$ and $\left.M e_{\mathrm{C}}=45\right)$. Likewise, we found group differences in the CREA C post-test $\left(U_{\mathrm{C}}=9074, p=0.005\right)$ in favor of the experimental group $(M e=80)$ vs. the control group $(M e=77.5)$, indicating a change in creativity values from medium (pre-test) to high (post-test)

TABLE 4 | Mann-Whitney U-test for creativity and life satisfaction (pre/post-test), by group.

\begin{tabular}{|c|c|c|c|c|c|c|}
\hline & \multicolumn{6}{|c|}{ Control/Experimental groups } \\
\hline & $\begin{array}{c}\text { U de Mann- } \\
\text { Whitney }\end{array}$ & $\begin{array}{c}\text { W de } \\
\text { Wilcoxon }\end{array}$ & $z$ & $\begin{array}{l}\text { Sig. Asint. } \\
\text { (bilateral) }\end{array}$ & $\boldsymbol{D}$ & $\boldsymbol{R}$ \\
\hline \multicolumn{7}{|c|}{ Creativity } \\
\hline \multicolumn{7}{|l|}{ Pre-test } \\
\hline CREA A & 8723 & 21926 & -3.288 & $0.001^{\star}$ & 0.369 & 0.181 \\
\hline CREA B & 9435 & 22638 & -2.333 & $0.02^{\star}$ & 0.278 & 0.138 \\
\hline CREA C & 9354 & 22557 & -2.444 & $0.015^{\star}$ & 0.302 & 0.149 \\
\hline \multicolumn{7}{|c|}{ Post-test } \\
\hline CREA A & 10765 & 20356 & -0.553 & 0.58 & -0.065 & -0.033 \\
\hline CREA B & 10718 & 20309 & -0.615 & 0.538 & -0.082 & -0.041 \\
\hline CREA C & 9074 & 18665.5 & -2.819 & $0.005^{\star}$ & -0.264 & -0.131 \\
\hline \multicolumn{7}{|c|}{ Life Satisfaction } \\
\hline \multicolumn{7}{|l|}{ Pre-test } \\
\hline OLS & 9936.5 & 19527.5 & -1.71 & 0.087 & -0.201 & -0.100 \\
\hline SWLS & 10559.5 & 20150.5 & -0.828 & 0.408 & -0.116 & -0.058 \\
\hline \multicolumn{7}{|c|}{ Post-test } \\
\hline OLS & 9883.5 & 19474.5 & -1.774 & 0.076 & -0.166 & -0.082 \\
\hline SWLS & 9082 & 18673 & -2.806 & $0.005^{\star}$ & -0.221 & -0.110 \\
\hline
\end{tabular}

and a positive effect of the emotionally positive and creative intervention in the classroom for this group in this creativity test.

In the pre-test, the mean difference in creativity by group turned out to be small in each test $\left(d_{\mathrm{A}}=0.369, r=0.181\right.$; $d_{\mathrm{B}}=0.278, r=0.138$ and $\left.d_{\mathrm{C}}=0.302, r=0.149\right)$. In the post-test, we also obtained a small mean difference in creativity (CREA C) per group $\left(d_{\mathrm{Cpt}}=0.264, r=0.131\right)$.

When we consider the creativity differences in the percentages of change pre/post-test by groups (see Table 5), the Mann Whitney $U$ test calculated from the normality data indicates that there are significant median changes in all the calculations of this variable $\left(U_{\mathrm{A}}=6476.5, p=0.000 ; U_{\mathrm{B}}=6928, p=0.000\right.$ and $\left.U_{\mathrm{C}}=5389.5, p=0.000\right)$ in the pre-test). The median creativity scores of the control group $\left(M e_{\mathrm{A}}=40 ; M e_{\mathrm{B}}=50\right.$ and $\left.M e_{\mathrm{C}}=80\right)$ were higher than those of the experimental group $\left(M e_{\mathrm{A}}=25 ; M e_{\mathrm{B}}=35\right.$ and $\left.M e_{\mathrm{C}}=45\right)$ in all tests; while in the post-test, the highest median scores were in the CREA C test of the experimental group $\left(M e_{\mathrm{C}}=80\right)$ vs. control group $\left(M e_{\mathrm{C}}=77.5\right)$. This confirms that the intervention program had a more significant effect on the change in median scores than those obtained by the experimental group on the CREA C test after the intervention, when compared to the control group.

For life satisfaction, we used non-parametric statistics based on the normality data obtained. The Mann Whitney $U$ test calculated (see Table 4), did not find statistical significance $(\alpha=0.05)$ in the differences of medians of this variable, neither in the experimental nor in the control group in the OLS test. However, in the SWLS test, after the intervention there was a significant difference $(U=9082, p=0.005)$ in favor of the experimental group $(M e=6$, on a scale of 1-7) compared to the control group $(M e=5.6)$, with higher life satisfaction and a small difference in the effect size of this group after the intervention as indicated by Cohen's value $\left(d_{\mathrm{pt}}=0.221, r=0.110\right)$.

After further analysis of the differences in the percentages of change of life satisfaction means in the pre-test and post-test moments in each of the groups, the Mann Whitney $U$ tests for independent samples calculations confirm the non-existence of significant differences in medians in the OLS scale, and significant differences existing between the median life satisfaction scores

TABLE 5 | Mann-Whitney U-test for percentages of change in creativity and life satisfaction (pre/post-test), by group.

\begin{tabular}{|c|c|c|c|c|}
\hline & \multicolumn{4}{|c|}{ Control/Experimental groups } \\
\hline & $\begin{array}{c}\text { U de Mann- } \\
\text { Whitney }\end{array}$ & $\begin{array}{c}\text { W de } \\
\text { Wilcoxon }\end{array}$ & $\boldsymbol{Z}$ & $\begin{array}{l}\text { Sig. Asint. } \\
\text { (bilateral) }\end{array}$ \\
\hline \multicolumn{5}{|l|}{ Creativity } \\
\hline$\%$ CREA A & 6476.5 & 16067.5 & -6.325 & $0.000^{\star}$ \\
\hline$\%$ CREA B & 6928 & 16519 & -5.721 & $0.000^{\star}$ \\
\hline \% CREA C & 5389.5 & 14980.5 & -7.817 & $0.000^{\star}$ \\
\hline \multicolumn{5}{|c|}{ Life Satisfaction } \\
\hline$\%$ OLS & 9867 & 19458 & -1.755 & 0.079 \\
\hline$\%$ SWLS & 9483.5 & 19074.5 & -2.288 & $0.022^{\star}$ \\
\hline
\end{tabular}

CREA A, B, C = A, B, C CREA test pictures; SWLS (Satisfaction with Life Scale); OLS (Overall Life Satisfaction); $U=$ Mann-Whitney test; $Z$ = standardized value; $p=$ Statistical significance, ${ }^{*} p<0.005$. 
evaluated with the SWLS $(U=9483, p=0.022)$ (see Table 5), in the experimental group after the intervention $(\mathrm{Me}=6$, on a scale of 1-7) compared to the control group $(\mathrm{Me}=5.6)$. These results indicate that the emotionally positive and creative intervention in the classroom improved the results of this variable (measured with SWLS) in the students who worked with this methodology in their classroom, compared to those who worked with a traditional methodology.

\section{Effects of the Program on Creativity and Life Satisfaction: Differences Between Genders}

When we study the differences in pre-measure and post-measure separately, the Mann Whitney $U$ test, calculated from the normality data, show us (see Table 6) a significant level $<0.05$ that there are median differences by gender in CREA B pre-test $\left(U_{\text {Bpre-test }}=6637, p=0.046\right)$, in favor of females $(M e=45)$ compared to males $(M e=30)$, and in the post-test $\left(U_{\text {Bpost }}=6626\right.$ $p=0.044)$, also in favor of females $(M e=50)$ compared to that of males $(M e=45)$. Women's creativity is medium and above in the post-test compared to the pre-test, although the effect size is small in both cases $\left(d_{\mathrm{Bpre}}=0.263, r=0.131 ; d_{\mathrm{Bpt}}=0.288\right.$, $r=0.142$ ), considering the index established by Cohen (1988). These analyses cannot determine whether there were any gender differences as an effect of the program, therefore also a change analysis was performed.

When we calculated the differences in the percentages of change of creativity pre/post-test by gender (see Table 7), the Mann Whitney $U$ test for independent samples

TABLE 6 | Mann-Whitney U-test for creativity and life satisfaction (pre/post-test), by gender.

\begin{tabular}{|c|c|c|c|c|c|c|}
\hline & \multicolumn{6}{|c|}{ Females/Males } \\
\hline & $\begin{array}{c}\text { U de Mann- } \\
\text { Whitney }\end{array}$ & $\begin{array}{c}W \text { de } \\
\text { Wilcoxon }\end{array}$ & $z$ & $\begin{array}{l}\text { Sig. Asint. } \\
\text { (bilateral) }\end{array}$ & $d$ & $R$ \\
\hline \multicolumn{7}{|c|}{ Creativity } \\
\hline \multicolumn{7}{|l|}{ Pre-test } \\
\hline CREA A & 7801.5 & 10147.5 & -0.138 & 0.890 & 0.017 & 0.01 \\
\hline CREA B & 6637.5 & 8983.5 & -1.993 & $0.046^{\star}$ & 0.263 & 0.131 \\
\hline CREA C & 7057.5 & 9403.5 & -1.325 & 0.185 & 0.249 & 0.124 \\
\hline \multicolumn{7}{|c|}{ Post-test } \\
\hline CREA A & 7805 & 10151 & -0.132 & 0.895 & 0.032 & 0.016 \\
\hline CREA B & 6626 & 8972 & -2.01 & $0.044^{\star}$ & 0.288 & 0.142 \\
\hline CREA C & 6957.5 & 9303.5 & -1.484 & 0.138 & 0.139 & 0.070 \\
\hline \multicolumn{7}{|c|}{ Life Satisfaction } \\
\hline \multicolumn{7}{|l|}{ Pre-test } \\
\hline OLS & 7294.5 & 9640.5 & -0.973 & 0.33 & 0.117 & 0.058 \\
\hline SWLS & 6157 & 8503 & -2.758 & $0.006^{\star}$ & 0.358 & 0.176 \\
\hline \multicolumn{7}{|c|}{ Post-test } \\
\hline OLS & 7403 & 9749 & -0.791 & 0.429 & 0.103 & 0.051 \\
\hline SWLS & 7267 & 9613 & -0.99 & 0.322 & 0.244 & 0.121 \\
\hline
\end{tabular}

CREA A, B, C = A, B, C CREA test pictures; SWLS (Satisfaction with Life Scale); OLS (Overall Life Satisfaction); $U=$ Mann-Whitney test; $Z$ = standardized value; $p=$ Statistical significance, ${ }^{*} p<0.005 ; d=$ Cohen's $d ; r=$ effect size.
TABLE 7 | Mann-Whitney $U$-test for percentages of change in creativity and life satisfaction (pre/post-test), by gender.

\begin{tabular}{lcccc}
\hline \multicolumn{4}{c}{ Females/Males } \\
\cline { 2 - 5 } & $\begin{array}{c}\text { U de Mann- } \\
\text { Whitney }\end{array}$ & $\begin{array}{c}\text { W de } \\
\text { Wilcoxon }\end{array}$ & $\boldsymbol{Z}$ & $\begin{array}{r}\text { Sig. Asint. } \\
\text { (bilateral) }\end{array}$ \\
\hline Creativity & & & & \\
\% CREA A & 7798 & 34826 & -0.144 & 0.885 \\
\% CREA B & 7717.5 & 34745.5 & -0.273 & 0.785 \\
\% CREA C & 7581 & 34609 & -0.494 & 0.622 \\
Life Satisfaction & & & & \\
\% OLS & 7594.5 & 34622.5 & -0.485 & 0.628 \\
\% SWLS & 7396.5 & 34424.5 & -30.79 & 0.429 \\
\hline
\end{tabular}

CREA A, B, C = A, B, C CREA test pictures; SWLS (Satisfaction with Life Scale); OLS (Overall Life Satisfaction); $U=$ Mann-Whitney test; $Z$ = standardized value; $p=$ Statistical significance, ${ }^{*} p<0.005$.

calculations found no significant mean differences in male and female creativity.

To calculate the difference in life satisfaction by gender, we also considered the results of the normality tests and calculated the Mann Whitney $U$ test. In Table 6 we can see, with a $\alpha=0.05$ level, that there is statistical significance only in the pre-test scores of the SWLS questionnaire $(U=6157, p=0.006)$. The life satisfaction of the students, at pre-test, was higher in females $(M e=5.6)$, than in males $(M e=5.1)$. The difference in the median effect size is small, in accordance with the critical value $\left(d_{\text {Dpre }}=0.358, r=0.176\right)$ developed by Cohen (1988).

In the calculations for the differences in the percentage of change pre/post-test of this variable by gender, we did not find significant variations in either measure (OLS and SWLS). The means result of life satisfaction increased in both genders from pre-test to post-test $\left(M_{\text {OLSpre-test }}\right.$ female $=7.7$ vs. male $=7.5$; $M_{\text {OLSpost-test }}$ female $=7.8$ vs. male $=7.6 ; M_{\text {SWLSpre-test }}$ female $=5.5$ vs. male $=5.1 ; M_{\text {SwLSpost-test }}$ female $=5.6$ vs. male $=5.3$ ) but did not reach statistical significance indicating that they were different in men and women (see Table 7).

\section{DISCUSSION AND CONCLUSION}

Our research had as objectives to describe the levels of creativity and life satisfaction of the university students in our sample, to assess the effects of an emotionally positive and creative intervention program on these variables, and to analyze possible differences by gender as a result of treatment/non-treatment.

Our data have indicated that the university students analyzed have moderate or medium creativity and high life satisfaction levels before condition treatment/no treatment, coinciding with another research results such as Reboredo-Santes et al. (2012), Velásquez (2015), Lavado Pantoja (2018) and De Ávila et al. (2019).

Without underestimating from the fact that these results are good, they indicate that there is still a long way to progress in the development of these competences. Much more if we already know from Álvarez-Santullano and De Prada Creo (2018) that university students lack high levels 
of professional skills such as creativity and that young Spanish university students, in comparison with Europeans, has a lower level of creativity and innovation (Secanella, 2016). Along this paper we have also discussed that life satisfaction is related to personal and social well-being, employability, and professional success. Therefore, to promote actions for the improvement of creativity and life satisfaction is, among others, a challenge for university and adult education (European Association for the Education of Adults [EAEA], 2019) in particular, and for the educational system and society in general.

We also wanted to analyze group and gender differences in creativity and life satisfaction, before and after the application of an emotionally positive and creative program integrated into regular university classroom. The results indicate relevant data with an impact on university educational practice.

On group analysis, we find that the emotionally positive and creative intervention program developed had a positive impact in favor of the experimental group in creativity (which went from medium in the pretest to high in the posttest) and life satisfaction when (which went from medium-high in the pretest to high in the posttest) compared to the control group.

There are many intervention programs that have been carried out in university classrooms with satisfactory results in creativity (Amabile, 1983; Allueva, 2004; Ma, 2006; Goda, 2019; Vally et al., 2019) and subjective well-being (Sin and Lyubomirsky, 2009; Bolier et al., 2013; Lorenzo and Matallanes, 2013; Párraga Gallardo, 2015; Marrero et al., 2016; Barrios et al., 2018) like ours. This allows us to affirm that creativity and life satisfaction skills can be learned, worked on, and be profitable for university classrooms.

In his review of the duration of these programs, Lorenzo Alegría (2017) indicated that there are short programs, from 10 to $12 \mathrm{~h}$; of medium duration, from 20 to $30 \mathrm{~h}$; and long programs, of two years' duration, with heterogeneous results. Our program was developed during a semester and achieved positive results, in line with other interventions such as those carried out by Vally et al. (2019), who offered a group of students who lived in the United Arab Emirates a creativity training program that ranged over an entire semester. Following the intervention, students were able to produce a greater number of ideas of an original nature and creative products.

In our research, the effect size evidenced by pre-test and post-test differences of creativity was small. It differs from other studies pointed out by Ma (2006) in which the effect size ranged from 0.47-0.76, medium-high, and Vally et al. (2019), who achieved a medium effect size. In turn, the effect size by group achieved for life satisfaction it was also small. Our data coincide with the results of some meta-analyses such as those of Sin and Lyubomirsky (2009) who analyzed 51 interventions with a total sample of 4,266 individuals. The effect sizes ranged from 0.31 to 0.84 , with $96 \%$ of effect sizes in the predicted, positive direction. The meta-analysis by Bolier et al. (2013) also evidences improvements in a total of 39 interventions analyzed, 19 of them in college students, although the effect size tends to be small, but stable over time after several months (Sin and Lyubomirsky, 2009;
Lyubomirsky et al., 2011; Davis and Zautra, 2013; Baños et al., 2014; Ovejero et al., 2015).

This result is modest but sufficiently relevant given the fact that life satisfaction is considered to be one essential aspect for the all-round education of citizens (European Commission, 2016), along with other skills such as innovation, entrepreneurship, and creativity. In addition, the studied variables are critical for work in a near future (Bouchard, 2014; Powell, 2018).

Regarding gender, we hypothesized that it would make significant differences in our dependent variables and that scores would be higher on the post-test. Our results show gender differences in creativity in favor of women at post-treatment moments, with an effect size small, in tune with the data of other studies that have been carried out with university students and whose evaluation test has been the CREA A as well (Bindu and Thomas, 2006; Kaufman, 2006; Miranda, 2007; Aranguren and Irazábal, 2012; Krumm et al., 2015; Elisondo and Donolo, 2016; Chiecher et al., 2018; Gamarra-Moscoso and Flores-Mamani, 2020). Other authors have also found significant differences in favor of women, like ours, but with other assessment measures and in more specific dimensions of creativity (Lee, 2005; Donolo and Elisondo, 2007; López-Martínez and Navarro-Lozano, 2008; Limiñana Gras et al., 2010).

However, the differences by gender in creativity found, were not confirmed by the analysis of differences in percentage of change. In this sense, we are forced to affirm that, although the above is true, and we were able to verify that creativity improved in the posttest, preferably in women, our study could not confirm these differences in change by gender and their data is more aligned with those of others researchers such as Maccoby and Jacklin (1974), Wright and Stone (1998), De Zubiría et al. (2003), Chacón and Moncada (2006), Matud et al. (2007), Baer and Kaufman (2008), Limiñana Gras et al. (2010), Bermejo et al. (2013) and Ramírez et al. (2019), among others, who concluded that creative potential is not significantly influenced by the gender variable.

This situation accounts for the difficulty of finding conclusive data on gender differences in creativity and invites us to continue investigating possible explanations and determinants of the heterogeneity of these results.

Finally, in life satisfaction, we did not find significant differences by gender. The means result of life satisfaction increased in both genders from pre-test to post-test but did not reach statistical significance indicating that they were different in men and women, coinciding with the results of other previous studies such as those of Alarcón (2000), Martínez (2004) and Gadermann et al. (2012) and meta-analysis such as those of BatzBarbarich et al. (2018).

As a conclusion, our study has shown that creativity and life satisfaction can be improved in university classrooms with intervention programs such as ours, taking into account that they are competencies demanded by companies (Bouchard, 2014) and that they can have a decisive character for achievement (Fernández-Berrocal and Ruiz Aranda, 2008; Figueiredo-Ferraz et al., 2009; Anwar et al., 2012; Belmonte, 2013; Saremi and Bahdori, 2015; Bernabé et al., 2017; Peña García et al., 2017) and, as we pointed out, to improve the employability of our students, 
productivity, and quality of work (Diener and Biswas-Diener, 2002; del Águila Ríos et al., 2019) and the capacity for innovation that today's society demands of us (European Commission, 2008), in agreement with the improvement guidelines of the Bologna plan, included in the Europe 2030 strategy (Sánchez Ruiz, 2020). The review by Gilar-Corbi et al. (2018), attests to the growing interest in recent years of teaching these contents and intentions to our higher education students.

Although the results have been positive and we have been able to demonstrate that the students who received this emotionally positive and creative training program improved their creativity and satisfaction with life, regardless of gender, compared to those who were immersed in the traditional methodology, we are aware that this effect can benefit from improvement.

Its impact and strength can be increased with experimental research and larger and more representative samples; with systematized and longer duration interventions that combines creativity and life satisfaction with the development of happiness, emotional intelligence and critical thinking and promote educational changes and more consistent improvements.

Future lines of research may broaden the scope of this study and contrast their results with forms of measurement different from those employed, which consider more social and emotional aspects and not so much cognitive ones, which could deepen in differential aspects by gender, as suggested by authors such as Costa et al. (1987), Bedin and Sarriera (2015), Azpiazu (2016), considering the heterogeneity of results found in the literature.

Another line of research could analyze differences in the impact of this type of intervention by age or university degree; make comparative analyses in different academic environments, contexts, or specific situations, to deepen in the study of individual variations, and the influence of intercultural and social factors in the development of these variables, taking into account the moderating effect of culture in each of them, as mentioned by authors such as Diener and Diener (1995), Alarcón (2001), Fernández-Berrocal et al. (2001), Cuadros et al. (2008), among others, in the search for a more effective intervention.

For more than 16 years we have been defending the need for a paradigm shift in universities to work in an integrated way on social and emotional skills and employability skills such as the development of critical thinking, motivation for science, entrepreneurship, and creativity, and providing

\section{REFERENCES}

Acevedo, G. A. V. (2012). La creatividad desde la perspectiva de estudiantes universitarios. REICE 10, 212-237.

Alarcón, R. (2000). Historia de la psicología en el perú: de la colonia a la república. Persona 4, 237-239.

Alarcón, R. (2001). Relaciones entre felicidad, género, edad y estado conyugal. Rev. Psicol. 19, 27-46. doi: 10.18800/psico.200101.002

Al-Attiyah, A., and Nasser, R. (2016). Gender and age differences in life satisfaction within a sex-segregated society: sampling youth in Qatar. Int. J. Adolesc. Youth 21, 84-95. doi: 10.1080/02673843.2013.808158

Allueva, P. T. (2004). Desarrollo del pensamiento creativo en el ámbito universitario. Anu. Filos. Psicol. Sociol. 7, 117-130. empirical evidence that this is possible and necessary for the benefits it brings.

We defend a differentiated and inclusive university education in competencies (Caballero-García, 2004, 2009) that ensures equality of opportunity, culture, and gender in the competencybased education (Caballero-García and Cifuentes, 2017; Caballero-García and Sánchez, 2018; Caballero-García et al., 2019) that people and societies need to ensure their well-being and progress. Just as we propose the generation of an educational culture and policy that involves the university curriculum in key competencies such as creativity and subjective and organizational well-being, and that transcends from the university classroom to personal, social, and working life.

\section{DATA AVAILABILITY STATEMENT}

The datasets presented in this study can be found in online repositories. The names of the repository/repositories and accession number(s) can be found below: https://repositorio.ucjc. edu/handle/20.500.12020/891.

\section{ETHICS STATEMENT}

The studies involving human participants were reviewed and approved by Comité Permanente de Integridad Académica de la UCJC. The patients/participants provided their written informed consent to participate in this study.

\section{AUTHOR CONTRIBUTIONS}

Both authors listed have made a substantial, direct, and intellectual contribution to the work, and approved it for publication.

\section{ACKNOWLEDGMENTS}

Study funded by Camilo José Cela University and Education Faculty, Madrid (Spain). We are grateful to young university students and teachers who volunteered their time to participate in the research.

Álvarez-Santullano, M. M., and De Prada Creo, E. (2018). Evaluación de las competencias profesionales a través de las prácticas externas: incidencia de la creatividad. Rev. Investig. Educ. 36, 203-219. doi: 10.6018/rie.36.1.27 5651

Amabile, T. M. (1983). The social psychology of creativity: a componential conceptualization. J. Pers. Soc. Psychol. 45, 357-376. doi: 10.1037/0022-3514. 45.2.357

Anwar, M. N., Aness, M., Khizar, A., Naseer, M., and Muhammad, G. (2012). Relationship of creative thinking with the academic achievements of secondary school students. Int. Interdiscip. J. Educ. 1, 44-47.

Aranguren, M., and Irazábal, N. (2012). Diseño de una escala para la evaluación del comportamiento creativo en diferentes dominios. Cienc. Psicológicas 6, 29-41. doi: $10.22235 /$ cp.v6i1.60 
Arocena, F. A. L., Verdugo Lucero, J. C., and Guzmán Muñiz, J. (2005). Satisfacción con la vida de algunos colectivos mexicanos: una discusión sobre la psicología del bienestar subjetivo. Ensen. Investig. Psicol. 10, 325-336.

Arrieta Arias, K. C. (2019). Efecto Del Aprendizaje Colaborativo en el Desarrollo Del Pensamiento Creativo en la Enseñanza de Las Ciencias Naturales. Doctoral dissertation. Barranquilla: Universidad de la Costa.

Arroyo-Resino, D., and Carrasco-Temiño, M. A. (2017). Bienestar mental y rendimiento académico en estudiantes universitarios: un programa de psicología positiva. Psicol. Educ. 18, 155-163.

Atienza, F. L., Pons, D., Balaguer, I., and Merita, M. G. (2000). Propiedades psicométricas de la escala de satisfacción con la vida en adolescentes. Psicothema 12, 314-319.

Azpiazu, L. I. (2016). El Ajuste Escolar: Un Modelo Explicativo en Función de Variables Contextuales y Personales. Doctoral dissertation. Leioa: Universidad del País Vasco.

Badii, M. H., Castillo, A. W., and Landeros, J. (2017). Precisión de los índices estadísticos: técnicas de jacknife y bootstrap. Innovaciones Negocios 4, 63-68.

Baer, J., and Kaufman, J. C. (2008). Gender differences in creativity. J. Creat. Behav. 42, 75-105. doi: 10.1002/j.2162-6057.2008.tb01289.x

Baños, R. M., Etchemendy, E., Farfallini, L., García-Palacios, A., Quero, S., and Botella, C. (2014). EARTH of well-being system: a pilot study of an information and communication technology-based positive psychology intervention. J. Posit. Psychol. 9, 482-488. doi: 10.1080/17439760.2014.927906

Barbachán Ruales, E. A., Pareja Pérez, L. B., and Coll Cárdenas, A. M. H. (2020). Niveles de creatividad y rendimiento académico en los estudiantes del área de metal mecánica de la universidad nacional de educación de Perú. Rev. Universidad Sociedad 12, 202-208.

Barrios, M. A., Villarroel, M. E. S., and de Faria, L. C. P. (2018). Efectos de un programa de felicidad sobre el rendimiento académico de estudiantes universitarios. REDHECS 13, 34-54.

Batz-Barbarich, C., Tay, L., Kuykendall, L., and Cheung, H. K. (2018). A metaanalysis of gender differences in subjective well-being: estimating effect sizes and associations with gender inequality. Psychol. Sci. 29, 1491-1503. doi: 10. 1177/0956797618774796

Bedin, L. M., and Sarriera, J. C. (2015). A comparative study of the subjective wellbeing of parents and adolescents considering gender, age and social class. Soc. Indic. Res. 120, 79-95. doi: 10.1016/j.socscimed.2008.12.029

Belmonte, V. M. (2013). Inteligencia Emocional y Creatividad: Factores Predictores Del Rendimiento Académico. Doctoral dissertation. Universidad de Murcia: Murcia University Publications Service.

Bermejo, R., Prieto, M., Fernández, M., Soto, G., and Sainz, M. (2013). A cognitivecreative profile of emotional talent. New Approaches Educ. Res. 2, 12-16. doi: 10.7821/naer.2.1.12-16

Bernabé, R., Gálvez, M., and Álvarez, R. (2017). Relación entre el pensamiento creativo y el rendimiento académico de los estudiantes del quinto año de secundaria. ciencia y desarrollo. Universidad Alas Peruanas 20, 93-98. doi: 10.21503/cyd.v20i2.1495

Bernal, A. C. A. L., Arocena, F. A. L., and Ceballos, J. C. M. (2011). Bienestar subjetivo y satisfacción con la vida de familia en adolescentes mexicanos de bachillerato. Psicol. Iberoam. 19, 17-26. doi: 10.48102/pi.v19i2.225

Bindu, P., and Thomas, I. (2006). Gender differences in emotional intelligence. Psychol. Stud. 51, 261-268.

Bisegger, C., Cloetta, B., Von Bisegger, U., Abel, T., and Ravens-Sieberer, U. (2005). Health-related quality of life: gender differences in childhood and adolescence. Soz. Präventivmed. 50, 281-291. doi: 10.1007/s00038-005-4094-2

Bolier, L., Haverman, M., Westerhof, G. J., Riper, H., Smit, F., and Bohlmeijer, E. (2013). Positive psychology interventions: a meta-analysis of randomized controlled studies. BMC Public Health 13:119. doi: 10.1186/1471-2458-13-119

Borrero, M. A., Villalba Ruiz, E. B., Pérez Moreno, P. J., and Fernández Bellido, M. (2010). Evidencias de validez de la adaptación al español de la escala de satisfacción con la vida (SWLS) en una muestra de estudiantes universitarios. Metodología Encuestas 12, 45-62.

Botín Fundation (2012). Buenos Días Creatividad. Hacia una Educación que Despierte la Capacidad de Crear. Botín Fundación. Available online at: https://fundacionbotin.org/89dguuytdfr276ed_uploads/EDUCACION/ creatividad/buenosdiascreatividad.pdf (accessed November 17, 2021).

Bouchard, G. (2014). The quality of the parenting alliance during the transition to parenthood. Can. J. Behav. Sci. 46, 20-28. doi: 10.1037/a0031259
Caballero-García, P. A. (2004). “Cómo enfocar la educación emocional dentro del aula desde la perspectiva de género," in Internacional Orientación, Inclusión social y desarrollo de la carrera Conference (A Coruña: Universidad de La Coruña), 546-550.

Caballero-García, P. A. (2009). Competencias Emocionales: Aprendizaje, Desarrollo y Evaluación. Madrid: Universidad Camilo José Cela.

Caballero-García, P. A., and Cifuentes, E. (2017). "Gender, emotional intelligence, aptitude and mathematical performance," in Proceedings of the 4th International Conference on Education and Social Sciences (INTCESS 2017), Estambul. doi: 10.18769/ijasos.309313

Caballero-García, P. A., and Sánchez, S. (2018). La felicidad en estudiantes universitarios. ¿Existen diferencias según género, edad o elección de estudios? REIFOP 21, 1-18. doi: 10.6018/reifop.21.3.336721

Caballero-García, P. A., Sánchez-Ruiz, S., and Almagro, M. L. (2019). Análisis de la creatividad de los estudiantes universitarios: diferencias por género, edad y elección de estudios. Educación 22, 1-24. doi: 10.5944/educxx1.22552

Cabañero, M. J., Martínez, M. R., García, J. C., Cortés, M. I. O., Ferrer, A. R., and Herrero, B. T. (2004). Fiabilidad y validez de la escala de satisfacción con la vida de diener en una muestra de mujeres embarazadas y puérperas. Psicothema 16, 448-455.

Campbell, A., Converse, P. E., and Rodgers, W. L. (1976). The Quality of American Life: Perceptions, Evaluations and Satisfactions. New York, NY: Russel Sage Foundation.

Campbell, D. T., and Fiske, D. W. (1959). Convergent and discriminant validation by the multitreat-multimethod matrix. Psychol. Bull. 56, 81-105. doi: 10.1037/ h0046016

Campbell, D. T., and Stanley, J. C. (1966). Experimental and Quasi-Experimental Designs for Research. Chicago: Rand McNally.

Cañero, M. P., Mónaco, E. G., and Montoya, I. C. (2019). La inteligencia emocional y la empatía como factores predictores del bienestar subjetivo en estudiantes universitarios. Eur. J. Investig. Health Psychol. Educ. 9, 19-29. doi: 10.30552/ ejihpe.v9i1.313

Cardona, D., and Agudelo, H. B. (2007). Satisfacción personal como componente de la calidad de vida de los adultos de Medellín. Rev. Salud Pública 9, 541-549. doi: 10.1590/S0124-00642007000400006

Carnero Sánchez, M., Torres Miranda, T., and Tarrió Martínez, C. O. (2020). Creatividad, Potencialidad y Talento en la Educación Superior Hacia el 2030. Cuba University Editorial: Cuba University Publications Service.

Casas, F., Alfaro, J., Sarriera, J. C., Bedin, L., Grigoras, B., Baltatescu, S. et al. (2015). El bienestar subjetivo en la infancia: estudio de la comparabilidad de 3 escalas psicométricas en 4 países de habla latina. Psicoperspectivas 14, 6-18.

Casas, F., Baltatescu, S., Bertrán, I., González, M., and Hatos, A. (2012). School satisfaction among adolescents: testing different indicators for its measurement and its relationship with overall life satisfaction and subjective well-being in Romania and Spain. Soc. Indic. Res. 111, 665-681. doi: 10.1007/s11205-0120025-9

Cenkseven-Önder, F. (2012). The influence of decision-making styles on early adolescents' life satisfaction. Soc. Behav. Pers. 40, 1523-1536. doi: 10.2224/sbp. 2012.40.9.1523

Chacón, Y., and Moncada, J. (2006). Relación entre personalidad y creatividad en estudiantes de educación física. Rev. Electron. Actual. Investig. Educ. 6, 1-19.

Chaplin, L. N. (2009). An examination of children's and adolescents's happiness. J. Happiness Stud. 10, 541-562. doi: 10.1007/s10902-008-9108-3

Chen, S. K., and Lin, S. S. (2014). The latent profiles of life domain importance and satisfaction in a quality of life scale. Soc. Indic. Res. 116, 429-445. doi: 10.1007/s11205-013-0309-8

Chiecher, A. C., Elisondo, R. C., Paoloni, P. V., and Donolo, D. S. (2018). Creatividad, género y rendimiento académico en ingresantes de ingeniería. Rev. Iberoam. Educ. Super. 9, 138-151. doi: 10.22201/iisue.20072872e.2018.24.269

Cohen, J. (1988). Statistical Power Analysis for the Behavioural Sciences, 2nd Edn. New York, NY: Lawrence Elbaum.

Cook, T. D., and Campbell, D. T. (1979). Quasi-Experimentation. Design and Analysis Issues for Field Settings. Chicago, IL: Rand McNally.

Cook, T. D., and Campbell, D. T. (1986). The causal assumptions of quasiexperimental practice. Synthese 28, 141-180.

Corbalán, F. J., and Limiñana Gras, R. M. (2010). El genio en una botella. El test CREA, las preguntas y la creatividad. Introducción al monográfico "El test CREA, inteligencia creativa". An. Psicol. 26, 197-205. 
Corbalán, F. J., González, L., Limiñana, R., Rabadán, R., and Donolo, D. (2009). Creatividad en Menores Infractores. El CREA Como Indicador Significativo. Comunica Forum. Mesa 2. V Congreso de Creatividad e Innovación. Cáceres: $\mathrm{V}$ Congreso de Creatividad e Innovación.

Corbalán, F. J., Martínez, F., Donolo, D., Alonso, C., Tejerina, M., and Limiñana, R. M. (2003). Crea. Inteligencia Creativa. Una Medida Cognitiva de la Creatividad. Madrid: TEA Ediciones.

Costa, P. T., Zonderman, A. B., McCrae, R. R., Huntley, J. C., Locke, B. Z., and Barbano, H. E. (1987). Longitudinal analyses of psychological well-being in a national sample: stability of mean levels. J. Gerontol. 42, 50-55. doi: 10.1093/ geronj/42.1.50

Cotec Fundation (2020). Informe Cotec 2020. Available online at: https://www.ayming.es/wp-content/uploads/sites/21/2020/05/INFORME_ COTEC_2020.pdf (accessed November 17, 2021).

Cox, B. F. (2003). The Relationship Between Creativity and Self-Directed Learning Among Adult Community College Students. Doctoral dissertation. Knoxville, TN: University of Tennessee.

Cuadros, J., Valencia, J., and Valencia, A. (2008). Creatividad: concepciones, estrategias y su estimulación en entornos educativos. Rev. Educ. Desarro. Soc. 6, 138-153.

Davis, M. C., and Zautra, A. J. (2013). An online mindfulness intervention targeting socioemotional regulation in fibromyalgia: results of a randomized controlled trial. Annu. Behav. Med. 46, 273-284. doi: 10.1007/s12160-013-9 513-7

De Ávila, M. R., Castañeda, G. C., and Sánchez, L. P. (2019). Manejo emocional en estudiantes de psicología. Educ. Cienc. 8, 19-29.

De La Torre, S. (1991). Manual de la Creatividad. Barcelona: Editorial Vicens Vives.

De Zubiría, J., Marlés, R., and Ramírez, A. (2003). Prueba De Creatividad: Manual. Bogotá: Instituto Alberto Merani.

del Águila Ríos, Y., Capelo, M. R. T. F., Varela, J. M. C., Antequera, J. G., and Barroso, J. A. A. (2019). Creatividad y tecnologías emergentes en educación. Int. J. Dev. Educ. Psychol. 3, 527-534. doi: 10.17060/ijodaep.2019.n1.v3.1529

Diener, E. (1994). El bienestar subjetivo. Intervención psicosocial. Rev. Sobre Igualdad Calid. Vida 3, 67-113.

Diener, E. (2000). Subjective well-being: the science of happiness and a proposal for a national index. Am. Psychol. 55, 34-43. doi: 10.1037/0003-066x.55.1.34

Diener, E., and Biswas-Diener, R. (2002). Will money increase subjective wellbeing? Soc. Indic. Res. 57, 119-169. doi: 10.1007/978-90-481-2350-6_6

Diener, E., and Diener, M. (1995). Cross-Cultural correlates of life satisfaction and self-esteem. J. Pers. Soc. Psychol. 68, 653-663. doi: 10.1037/0022-3514.68.4.653

Diener, E., Emmons, R., Larsen, R., and Griffin, S. (1985). The satisfaction with life scale. J. Pers. Assess. 49, 1105-1117. doi: 10.1207/s15327752jpa4901_13

Diener, E., Suh, E., Lucas, R., and Smith, H. (1999). Subjetive well-being: three decades of progress. Psychol. Bull. 125, 276-302. doi: 10.1037/0033-2909.125.2. 276

Donolo, D. S., and Elisondo, R. C. (2007). Creatividad para todos. Consideraciones sobre un grupo particular. An. Psicol. 23, 148-151.

Echegaray Antay, C. F. (2019). Estrategias de Aprendizaje y Creatividad en Estudiantes de la Facultad de Arquitectura de una Universidad Privada. Doctoral dissertation. Santiago de Surco: Universidad Marcelino Campagnat.

Elisondo, R. C. (2015). Evaluación de la Creatividad: Análisis de Variables Alternativas Relacionadas con la Forma y el Contenido de las Respuestas en el test CREA. Doctoral dissertation. Murcia: Universidad de Murcia.

Elisondo, R. C., and Donolo, D. (2011). Los estímulos en un test de creatividad. Incidencias según género, edad y escolaridad. Bol. Psicol. 101, 51-65.

Elisondo, R. C., and Donolo, D. (2016). Construcción y análisis de las propiedades psicométricas del Cuestionario de Acciones Creativas en población argentina. PSIENCIA. Revista Latinoamericana de Ciencia Psicológica, 8, 1-21. doi: 10. 5872/psiencia.v8i1.188

European Association for the Education of Adults [EAEA] (2019). Manifesto for Adult Liarning in the 21st Century: The Power and Joy of Learning. Bruxelles: EAEA.

European Commission (2008). Propuesta de Decisión del Parlamento Europeo y del Consejo Relativa al Año Europeo de la Creatividad y la Innovación 2009. Available online at: https://eur-lex.europa.eu/LexUriServ/LexUriServ.do?uri= COM:2008:0159:FIN:ES:PDF.
European Commission (2016). A New Start for Social Dialogue. Luxembourg: European Commission.

Fernández-Berrocal, P., and Ruiz Aranda, D. (2008). La inteligencia emocional en la educación. Rev. Electron. Investig. Psicoeduc. 6:421. doi: 10.25115/ejrep.v6i15. 1289

Fernández-Berrocal, P., Salovey, P., Vera, A., Ramos, N., and Extremera, N. (2001). Cultura, inteligencia emocional percibida y ajuste emocional: un estudio preliminar. Rev. Electron. Motivación Emoción 4, 1-15.

Figueiredo-Ferraz, H., Cardona, S., and Gil-Monte, P. (2009). Desgaste psíquico y problemas de saúde en estudiantes de psicologia. Psicol. Estud. 14, 349-353. doi: 10.1590/s1413-73722009000200016

Gadermann, A. M., Guhn, M., and Zumbo, B. (2012). Estimating ordinal reliability for likert-type and ordinal item response data: a conceptual, empirical, and practical guide. Pract. Assess. Res. Eval. 17, 1-13. doi: 10.1080/03610918.2021. 1974477

Gamarra-Moscoso, M. A., and Flores-Mamani, E. (2020). Pensamiento creativo y relaciones interpersonales en estudiantes universitarios. Investig. Valdizana 14, 159-168. doi: 10.33554/riv.14.3.742

Garaigordobil, M. (2003). Intervención Psicológica Para Desarrollar la Personalidad Infantil. Juego, Conducta Prosocial y Creatividad (Volumen 1). Madrid: Pirámide.

Garrett, F. (1953). Psychological aspects of physical disability. Phys. Ther. 33, 325-326. doi: 10.1093/ptj/33.6.325

Gavín-Chocano, Ó, and Molero-López, D. B. (2019). Análisis de la inteligencia emocional y satisfacción vital, su impacto sobre las relaciones interpersonales de personas con discapacidad intelectual. Rev. Educ. Inclusiva 12, 211-231. doi: 10.25115/psye.v11i3.2078

Gilar-Corbi, R., Pozo-Rico, T., and Castejón-Costa, J. L. (2018). Desarrollando la inteligencia emocional en educación superior: evaluación de la efectividad de un programa en tres países. Educación XX1 22, 161-187. doi: 10.5944/educxx1. 19880

Gilman, R., Huebner, E. S., Tian, L., Park, N., O’Byrne, J., Schiff, M., et al. (2008). Cross-national adolescent multidimensional life satisfaction reports: analyses of mean scores and response style differences. J. Youth Adolesc. 37, 142-154. doi: 10.1007/s10964-007-9172-8

Goda, S. H. (2019). Using edmodo in teaching MATLAB for developing cognitive and affective creative abilities among mathematics department students at tabuk university. J. Educ. Psychol. Sci. 20, 281-318. doi: 10.12785/jeps/200110

Graen, G. B. (1976). "Role-making processes within complex organizations," Handbook of Industrial and Organizational Psychology, ed. M. D. Dunnette (Chicago, IL: Rand McNally).

Haier, J. F., Black, W. C., Babin, B. J., Anderson, R. E., and Latham, R. (2014). Multivariate Data Analysis, 7th Edn. Saddle River, NJ: Pearson Prentice Hall.

Hernández Arteaga, I., Alvarado Pérez, J. C., and Luna, S. M. (2015). Creatividad e innovación: competencias genéricas o transversales en la formación profesional. Rev. Virtual Universidad Catolica Norte 1, 135-151.

Hidalgo Fuentes, S., Sospedra Baeza, M. J., and Martínez, I. (2018). Análisis de las inteligencias múltiples y creatividad en universitarios. Cienc. Psicológicas 12, 271-281. doi: 10.22235/cp.v12i2.1691

Jurado Guillen, N. N. (2019). Satisfacción con la Vida en Estudiantes de Una Academia Preuniversitaria de Chimbote. Doctoral dissertation. Cimbote: Universidad Católica Los Ángeles Cimbote.

Kaplan, R. M., and Saccuzzo, D. P. (2009). Psychological Testing: Principles Applications and Issues, 7 th Edn. Wadsworth: Cengage Learning.

Kaufman, J. C. (2006). Self-reported differences in creativity by ethnicity and gender. Appl. Cogn. Psychol. 20, 1065-1082. doi: 10.1002/acp.1255

Krumm, G., Rubilar, J. V., Lemos, V., and de Sapia, L. B. O. (2015). Percepción de la creatividad en niños, padres y pares: efectos en la producción creativa. Pensam. Psicol. 13, 21-32. doi: 10.11144/Javerianacali.PPSI13-2.pcnp

Lalive, R., Manai, M., and Stutzer, A. (2014). "Gender differences in well-being and equal rights," in Encyclopedia of Quality of Life and Well-Being Research. A. C. Michalos (Berlin: Springer), 2420-2424. doi: 10.1007/978-94-007-0753-5_4181

Lantarón, B. (2014). La empleabilidad en la universidad española. J. Educ. Teachers Trainers 5, 272-286.

Lantarón, B. S. (2012). Los Servicios de Orientación Profesional y Apoyo a los Estudiantes Universitarios en la Mejora de la Empleabilidad. Doctoral dissertation. Barcelona: Universidad de Barcelona. 
Lavado Pantoja, R. A. (2018). Inteligencia Emocional en Estudiantes de Enfermería de un Instituto Superior Tecnológico en Puente Piedra. Doctoral dissertation. Santiago de Surco: Universidad Ricardo Palma.

Lee, K. (2005). The relationship between creative thinking ability and creative personality of preschoolers. Int. Educ. J. 6, 194-199.

León, O. G., and García-Celay, I. M. (2015). Métodos de Investigación en Psicología y Educación: Las Tradiciones Cuantitativa y Cualitativa. New York, NY: McGrawHill.

Limiñana Gras, R. M. G., Corbalán, J. B., and Sánchez-López, M. P. (2010). Creatividad y estilos depersonalidad: aproximación a un perfil creativo en estudiantes universitarios. An. Psicol. 26, 273-278.

Limiñana-Gras, R. M. G., and Javier, F. (2010). Is creativity a modulating variable of the relationship between health and gender? School Health 21, 221-232.

López-Martínez, O., and Navarro-Lozano, J. (2008). Estudio comparativo entre medidas de creatividad: TCTT vs. CREA. An. Psicol. 24, 138-142.

Lorenzo Alegría, M. (2017). Contrastación Del Modelo de Inteligência Emocional de las Cuatro Ramas. Doctoral dissertation. Santa Cruz de Tenerife: Universidad de La Laguna.

Lorenzo, V. B., and Matallanes, B. F. (2013). Desarrollo y evaluación de competencias psicosociales en estudiantes universitarios a través de un programa de aprendizaje-servicio. Rev. Int. Educ. Para Justicia Soc. 2, 155-176.

Lozano-Díaz, A., Fernández-Prados, J. S., Canosa, V. F., and Martínez, A. M. M. (2020). Impactos del confinamiento por el COVID-19 entre universitarios: satisfacción vital, resiliencia y capital social online. Int. J. Sociol. Educ. 9, 79-104. doi: 10.17583/rise.2020.5925

Lukaschek, K., Baumert, J., Kruse, J., Meisinger, C., and Ladwig, K. H. (2017). Sex differences in the association of social network satisfaction and the risk for type 2 diabetes. BMC Public Health 17:379. doi: 10.1186/s12889-017-4323-7

Lyubomirsky, S., and Lepper, H. S. (1999). A measure of subjective happiness: preliminary reliability and construct validation. Soc. Indic. Res. 46:137. doi: $10.1017 /$ sjp. 2017.8

Lyubomirsky, S., Dickerhoof, R., Boehm, J. K., and Sheldon, K. M. (2011). Becoming happier takes both a will and a proper way: an experimental longitudinal intervention to boost well-being. Emotion 11:391. doi: 10.1037/ a0022575

Ma, H. H. (2006). A synthetic analysis of the effectiveness of single components and packages in creativity training programs. Creat. Res. J. 18, 435-446. doi: 10.1207/s15326934crj1804_3

Maccoby, E. E., and Jacklin, C. N. (1974). The Psychology of Sex Differences. Palo Alto, CA: Stanford University Press.

Marrero, R. J., Carballeira, M., Martin, S., Mejias, M., and Hernández, J. A. (2016). Eficacia de una intervención en psicología positiva combinada con terapia cognitivo conductual en estudiantes universitarios. An. Psicol. 32, 728-740. doi: 10.6018/analesps.32.3.261661

Martín, I. R., and Martín, L. R. (2012). Creatividad y educación: el desarrollo de la creatividad como herramienta para la transformación social. Prisma Soc. 9, 311-351.

Martínez Zaragoza, F. (2003). Características psicométricas del CREA (inteligencia creativa) un estudio con población española y argentina. Rev. Iberoam. Diagnóstico Eval. Psicol. 16, 71-83.

Martínez, P. (2004). Perspectiva temporal futura y satisfacción con la vida a lo largo del ciclo vital. Rev. Psicol. 22, 217-252. doi: 10.18800/psico.200402.003

Matud, M. P., Rodríguez, C., and Grande, J. (2007). Gender differences in creative thinking. Pers. Individ. Dif. 5, 1137-1147. doi: 10.1016/j.paid.2007. 03.006

Meo, A. I. (2010). Consentimiento informado, anonimato y confidencialidad en la investigación social. la experiencia Internacional y el caso de la Sociología en Argentina. Aposta 44, 1-30. doi: 10.1111/isss. 12001

Miguélez, B. A. (2016). Investigación social cualitativa y dilemas éticos: de la ética vacía a la ética situada. EMPIRIA 34, 101-119. doi: 10.5944/empiria.34.2016. 16524

Miranda, V. (2007). El pensamiento creativo en escolares de $5^{\circ}$ año básico pertenecientes a establecimientos municipalizados con jornada escolar completa. Cuad. Neuropsicol. 1, 174-371.

Montenegro, M., Córdoba, P., Córdoba Rosenow, P., and García Payares, A. (2017). Caracterización del bienestar subjetivo mediante la aplicación de la escala de satisfacción vital de diener en estudiantes de la corporación universitaria antonio josé de sucre en sincelejo durante el primer semestre de 2015. Encuentros 15, 145-156.

Motta Taminchi, F. D. M. (2019). Variables Psicológicas Asociadas a la Pobreza Material de los Estudiantes de la Institución Educativa Corazón de Jesús del distrito de San Juan Bautista, 2018. Doctoral dissertation. Chimbote: Universidad Católica Los Ángeles Chimbote.

Murphy, K. R., and Davidshofer, C. O. (2005). Psychological Testing: Principles and Applications, 6th Edn. Hoboken, NJ: Prentice Hall.

Naderi, H., Abdullah, R., Aizan, H. T., Sharir, J., and Kumar, V. (2009). Creativity, age and gender as predictors of academic achievement among undergraduate students. J. Am. Sci. 5, 101-112.

Nunnally, J. C. (1978). Psychometric Theory, 2nd Edn. New York, NY: McGrawHill.

Okun, M. A., Stock, W. A., Haring, M. J., and Witter, R. A. (1984). Health and subjective well-being: a meta-analyis. Int. J. Aging Hum. Dev. 19, 111-132. doi: 10.2190/QGJN-0N81-5957-HAQD

Onwuegbuzie, A. J., and Collins, K. M. (2007). A typology of mixed methods sampling designs in social science research. Qual. Rep. 12, 281-316.

Ovejero, M., Miguel-Vicente, C., Jarden, A., Velázquez, M., Köppl, L., and Vega, E. (2015). "The tuesday program: a pilot study about its efficacy," Poster in 4th World Congress on Positive Psychology, Lake Buena Vista. June 25-28.

Oviedo, H. C., and Arias, A. C. (2005). Aproximación al uso del coeficiente alfa de Cronbach. Rev. Colomb. Psiquiatr. 34, 572-580.

Párraga Gallardo, C. D. R. (2015). Eficacia de la Intervención Psicológica Basada en Estrategias Positivas. Doctoral dissertation. Seville: Universidad de Sevilla

Pathak, S. (2008). Classroom contribution: what do students perceive as fair assessment? J. Educ. Bus. 83, 360-368. doi: 10.3200/joeb.83.6. 360-368

Pavot, W., and Diener, E. (1993). The affective and cognitive contest of self-reports measures of subjective well-being. Soc. Indic. Res. 28, 1-20. doi: 10.1007/ BF01086714

Pavot, W., Diener, E. D., Colvin, C. R., and Sandvik, E. (1991). Further validation of the satisfaction with life scale: evidence for the cross-method convergence of well-being measures. J. Pers. Assess. 57, 149-161. doi: 10.1207/ s15327752jpa5701_17

Pedhazur, E. J., and Schmelkin, L. P. (1991). Measurement, Design, and Analysis: An Integrated Approach. Hillsdale, NJ: Erlbaum.

Peña García, F. A., Ezquerro Cordón, A., and López Fernández, V. (2017). Un estudio piloto de la relación entre la creatividad, las inteligencias múltiples y el rendimiento académico en estudiantes de educación obligatoria. Rev. Acad. Virtualidad 10, 31-46. doi: 10.18359/ravi.2850

Pérez-Díaz, V., and Rodríguez, J. C. (2010). La Cultura de la Innovación de los Jóvenes Españoles en el Marco Europeo. Madrid: Fundación Cotec para la Innovación Tecnológica.

Poquioma, U. Y. (2019). Satisfacción con la Vida y Funcionalidad Familiar en Estudiantes Universitarios de Lima Metropolitana. Doctoral dissertation. Lima: Universidad privada del norte de Lima

Porto, M. (2008). Evaluación para la competencia creativa en la educación universitaria. Cuad. Fac. Humanidades Cienc. Soc. 35, 77-90.

Powell, C. (2018). What's the Adaptability Quotient and Why is it Important?. Available online at: https://www.d2l.com/corporate/blog/adaptabilityquotient-important/ (accessed November 17, 2021)

Punch, M. (1986). The Politics and Ethics of Fieldwork. Thousand Oaks, CA: Sage.

Ramírez, P., and Fuentes, C. (2013). Felicidad y rendimiento académico: efecto moderador de la felicidad sobre indicadores de selección y rendimiento académico de alumnos de ingeniería comercial. Formación Universitaria 6, 21-30. doi: 10.4067/s0718-50062013000300004

Ramírez, Y., Navas Prado, M., and López, V. (2019). Un estudio sobre la creatividad, el género, la edad y las inteligencias múltiples en alumnos de Educación Secundaria Obligatoria de España. Praxis educativa 23, 1-16.

Reboredo-Santes, F., Mazadiego-Infante, T., and Ruiz-Carús, S. (2012). Estudio psicosocial de la inteligencia emocional en una muestra de universitarios. Exploratoris Observatorio Real. Glob. 3, 7-14. doi: 10.22201/fesi.20070780.2011. 3.1.27680

Reig, A., Cabrero, J. G., Ferrer, R. C., and Richart, M. M. (2001). La Calidad de Vida $y$ el Estado de Salud de los Estudiantes Universitarios. Alicante: Universidad de Alicante. 
Remor, E., Amorós-Gómez, M., and Carrobles, J. A. (2010). Eficacia de un programa manualizado de intervención en grupo para la potenciación de las fortalezas y recursos psicológicos. An. Psicol. 26, 49-57.

Rojas-Valverde, D., and Fallas-Campos, A. (2017). Percepción de satisfacción con la vida y actividad física en estudiantes universitarios de Costa Rica. Rev. Hispanoamericana Cienc. Salud. 3, 41-46.

Salovey, P., and Mayer, J. D. (1990). Emotional intelligence. Imagin. Cogn. Personal. 9, 185-211. doi: 10.2190/DUGG-P24E-52WK-6CDG

Sánchez Ruiz, S. (2020). Inteligencia Emocional, Creatividad, Bienestar Subjetivo y Rendimiento Académico en Alumnos Universitarios. Doctoral dissertation. Madrid: Universidad Camilo José Cela.

Saremi, H., and Bahdori, S. (2015). The relationship between critical thinking with emotional intelligence and creativity among elementary school principals in Bojnord city. Iran. Int. J. Life Sci. 9, 33-40. doi: 10.3126/ijls.v9i6.12684

Schmidt, R. C. (1997). Managing delphi surveys using nonparametric statistical techniques. Decis. Sci. 28, 763-774. doi: 10.1111/j.1540-5915.1997.tb01330.x

Secanella, J. (2016). Nuevas competencias para la empleabilidad de los estudiantes universitarios. Cuestión Univ. 7, 40-47.

Serrano, M. (2004). Creatividad: definiciones, antecedentes y aportaciones. Rev. Digit. Univ. 5, 1-17.

Sin, N. L., and Lyubomirsky, S. (2009). Enhancing well-being and alleviating depressive symptoms with positive psychology interventions: a practice-friendly meta-analysis. J. Clin. Psychol. 65, 467-487. doi: $10.1002 /$ jclp.20593

Smith, K. W., Avis, N. E., and Assmann, S. F. (1999). Distinguishing between quality of life and health status in quality of life research: a metaanalysis. Qual. Life Res. 8, 447-459. doi: 10.1023/a:1008928518577

Sternberg, R. J. (1988). The Triarchic Mind: A Theory of Human Intelligence. New York, NY: Viking. doi: 10.1007/978-94-010-9437-5_3

Stuart, E. A., and Rubin, D. B. (2008). "Best practices in quasi-experimental designs: matching methods for causal inference," in Best Practices in Quantitative Methods, ed. J. Osborne (Thousand Oaks, CA: Sage), 155-176. doi: 10.4135/ 9781412995627.d14

Tegano, D. W., and Moran, J. D. (1989). Sex differences in the original thinking of preschool and elementary school children. Creat. Res. J. 2, 102-110. doi: $10.1080 / 10400418909534303$

Tomyn, A., and Weinberg, M. (2018). Resilience and subjective wellbeing: a psychometric evaluation in young Australian adults. Aust. Psychol. 53, 68-76. doi: 10.1111/ap.12251

Tristán López, A., and Mendoza González, L. (2016). Taxonomías sobre creatividad. Rev. Psicol. 34, 147-183. doi: 10.18800/psico.201601.006

Vally, Z., Salloum, L., AlQedra, D., El Shazly, S., Albloshi, M., Alsheraifi, S., et al. (2019). Examining the effects of creativity training on creative production, creative self-efficacy, and neuro-executive functioning. Think. Skills Creat. 31, 70-78. doi: 10.1016/j.tsc.2018.11.003

Vázquez, C., Duque, A., and Hervás, G. (2013). Satisfaction with life scale in a representative sample of spanish adults: validation and normative data. Spanish J. Psychol. 16, 1-15. doi: 10.1017/sjp. 2013.82

Velásquez, P. R. (2015). Evaluación de las Competencias Emocionales de los Profesores Tutores Del Colegio San Agustín de Lima, en Función a Los Resultados de la Aplicación del Inventario de Inteligencia Emocional Baron (I-CE). Doctoral dissertation. Piura: Universidad de Piura.

Villamizar Acevedo, G. (2012). La creatividad desde la perspectiva de estudiantes universitarios. REICE 10, 212-237.

Vizoso, C. (2019). Resiliencia, optimismo y estrategias de afrontamiento en estudiantes de ciencias de la educación. Psychol. Soc. Educ. 11, 367-377. doi: 10.25115/psye.v11i3.2280

Weisberg, R. (1988). "Problem solving and creativity," in The Nature of Creativity, ed. R. J. Sternberg (Cambridge: Cambridge University Press), $148-176$.

Woynarowska, B., Tabak, I., and Mazur, J. (2004). Self-reported health and life satisfaction in school-aged children in Poland and other countries in 2002. Med. Wieku Rozwoj. 8, 535-350.

Wright, B., and Stone, M. (1998). Diseño de Mejores Pruebas: Utilizando la Técnica de Rasch. Ciudad de México: Ceneval.

Zheng, R. C., and Xiao, B. L. (1983). A study of the creativity of high school students. Acta Psychol. Sin. 15, 445-452.

Conflict of Interest: The authors declare that the research was conducted in the absence of any commercial or financial relationships that could be construed as a potential conflict of interest.

Publisher's Note: All claims expressed in this article are solely those of the authors and do not necessarily represent those of their affiliated organizations, or those of the publisher, the editors and the reviewers. Any product that may be evaluated in this article, or claim that may be made by its manufacturer, is not guaranteed or endorsed by the publisher.

Copyright (C) 2021 Caballero-García and Sánchez Ruiz. This is an open-access article distributed under the terms of the Creative Commons Attribution License (CC BY). The use, distribution or reproduction in other forums is permitted, provided the original author(s) and the copyright owner(s) are credited and that the original publication in this journal is cited, in accordance with accepted academic practice. No use, distribution or reproduction is permitted which does not comply with these terms. 


\section{APPENDIX}

EPROCREU Program. Structure, activities, and objectives.

\begin{tabular}{|c|c|c|c|}
\hline \multicolumn{2}{|c|}{ Creativity (Module I) } & \multicolumn{2}{|c|}{ Positive emotions (Module II) } \\
\hline Name of the activity & Objective & Name of the activity & Objective \\
\hline $\begin{array}{l}\text { Case studies and creative } \\
\text { decision making }\end{array}$ & $\begin{array}{l}\text { Observe behaviors in different work teams } \\
\text { when faced with a problem related to their } \\
\text { subject. }\end{array}$ & Emocional weekly & $\begin{array}{l}\text { Observe in an introspective way everything that } \\
\text { makes them feel happy throughout a week. }\end{array}$ \\
\hline $\begin{array}{l}\text { Innovate educational, } \\
\text { organizational and functional } \\
\text { aspects of the center. }\end{array}$ & $\begin{array}{l}\text { Use concepts learned in class, apply them } \\
\text { to a real-life case, working from the different } \\
\text { roles implied by the hat that the student has } \\
\text { been given at random. }\end{array}$ & Dictionary of emotions & $\begin{array}{l}\text { Label emotions that have taken place throughout } \\
\text { the day. }\end{array}$ \\
\hline $\begin{array}{l}\text { Innovate educational, } \\
\text { organizational and functional } \\
\text { aspects of the center. }\end{array}$ & $\begin{array}{l}\text { Formulate a problem related to the subject } \\
\text { and agree on creative solutions. }\end{array}$ & Box of feelings & $\begin{array}{l}\text { Distribute emotions based on the subjective label } \\
\text { provided }\end{array}$ \\
\hline We innovate in education & $\begin{array}{l}\text { Improve the educational problem-solving } \\
\text { process and ask yourself what you want to } \\
\text { innovate. }\end{array}$ & Couples & $\begin{array}{l}\text { Choose the emotions that most define us and } \\
\text { share them in couple. }\end{array}$ \\
\hline I get bored & $\begin{array}{l}\text { Identify the steps of the research process } \\
\text { by reading an article, pose research } \\
\text { problems and come up with creative } \\
\text { solutions using the SCAMPER technique. }\end{array}$ & Emocional range & Give positive emotional feedback to others. \\
\hline Match images & $\begin{array}{l}\text { Find relationships between objects, } \\
\text { apparently very different }\end{array}$ & I empathize with your emotion & Identify and understand the emotions of others. \\
\hline Creativity to undertake. & $\begin{array}{l}\text { Bring out the natural skills that have value in } \\
\text { the professional field }\end{array}$ & Role playing tutor & $\begin{array}{l}\text { Put into practice assertiveness and empathy linked } \\
\text { to professional teaching practice. }\end{array}$ \\
\hline Creative problem solving & $\begin{array}{l}\text { Seek creative solutions to the problems } \\
\text { raised in order to achieve greater reasoning } \\
\text { and emotional security toward the } \\
\text { challenges of the subject that is applied. }\end{array}$ & Sociograma & Identify the roles within the classroom. \\
\hline \multirow[t]{5}{*}{ Reflect and associate } & $\begin{array}{l}\text { Encourage reflection and association of } \\
\text { ideas on certain key concepts }\end{array}$ & Musicalia & $\begin{array}{l}\text { Assess the importance of music and the rest of the } \\
\text { senses and how its affects my writing, my } \\
\text { concentration and my mood. }\end{array}$ \\
\hline & & Cooperative history of emotions & $\begin{array}{l}\text { Identify the most characteristic aspects of each of } \\
\text { the basic emotions through stories and from } \\
\text { cooperative work }\end{array}$ \\
\hline & & Information sources & $\begin{array}{l}\text { Improve the processes of search and academic } \\
\text { and scientific use of information and analyze the } \\
\text { influence of happiness and subjective well-being in } \\
\text { organizations. }\end{array}$ \\
\hline & & Today I feel... & Define how the student feels before and after class. \\
\hline & & How much am I worth? & $\begin{array}{l}\text { Promote social and linguistic skills. Being able to } \\
\text { detect in oneself not only what he knows, but what } \\
\text { he knows how to do, through an introspective } \\
\text { analysis. }\end{array}$ \\
\hline
\end{tabular}

